\title{
Genetic factors in animal models of intestinal inflammation
}

\author{
R BALFOUR SARTOR MD
}

\begin{abstract}
RB SARTOR. Genetic factors in animal models of intestinal inflammation. Can J Gastroenterol 1995;9(3):147-152. The critical importance of host genetic susceptibility in determining chronicity, aggressiveness and complications of intestinal inflammation is clearly demonstrated by studies of inbred rodents, transgenic rats and spontaneous mutants. Inbred Lewis rats challenged by purified bacterial cell wall polymers, indomethacin or small bowel bacterial overgrowth develop chronic granulomatous intestinal inflammation with fibrosis and extraintestinal manifestations, whereas Fischer (major histocompatibility complex identical to Lewis) and Buffalo rats identically stimulated demonstrate only selflimited enterocolitis with no chronic inflammation, fibrosis, granulomas or extraintestinal inflammation. Similar differential patterns of intestinal inflammation are apparent in inbred mouse strains challenged with trinitrobenzene-sulphonic acid, Citrobacter freundii or backcrossed with T cell receptor deficient (knockout) mice. The dominant role of genetic background in induction of intestinal inflammation is further documented by spontaneous colitis which develops in spontaneously mutant mice, cotton-top tamarins, human leukocyte antigen-B27/ 32 microglobulin transgenic rats and mice with targeted deletions of certain immunoregulatory cytokine and T lymphocyte genes. Identification of the immunological mechanisms of host genetic susceptibility and the genetic basis of spontaneous colitis should provide new insights into the pathogenesis of human inflammatory bowel disease.
\end{abstract}

Key Words: Animal models, Enterocolitis, Experimental colitis, Genetic susceptibility, Intestinal inflammation

\section{Facteurs génétiques dans des modèles animaux d'inflammation intestinale}

RÉSUMÉ : La grande importance de la sensibilité génétique de l'hôte dans la détermination de la chronicité, de l'agressivité et des complications de l'inflammation de l'intestin est fortement mise en évidence par des études menées chez des

voir page suivante

Center for Gastrointestinal Biology and Disease, University of North Carolina, Chapel Hill, North Carolina, USA

Correspondence: Dr R Balfour Sartor, Division of Digestive Diseases and Nutrition, School of Medicine, Department of Medicine, CB\# 7080, Room 326 Burnett-Womack Building, University of North Carolina at Chapel Hill, Chapel Hill, NC 27599-7080, USA. Telephone (919) 966-0149, Fax (919) 966-6842, e-mail rbs@med.unc.edu

This paper was presented at the Basic Research and Clinical Implications in IBD meeting, April 6 to 9, 1994, held in Victoria, British Columbia. This paper has also been published in Sutherland LR, et al, eds. Inflammatory Bowel Disease: Basic Research, Clinical Implications and Trends in Therapy. Boston, Dordrecht and London: Kluwer Academic Publishers, 1994
$\mathrm{C}$ INICAL INVESTIGATORS HAVE compellingly documented a genetic component in ulcerative colitis and Crohn's disease (1). There is an increased incidence of inflammatory bowel disease (IBD) in family members, a predilection for these disorders in certain genetically defined ethnic groups, higher concordance of disease in monozygotic versus dizygotic twins and familial patterns of clinical phenotypes. However, human genetic research has not yet provided clinically useful disease susceptibility markers nor an understanding of the immunopathogenesis of IBD.

The critical importance of host genetic susceptibility in determining chronicity, aggressiveness and complications of intestinal inflammation is clearly demonstrated by studies in inbred rodents, transgenic rats, gene knockout mice and spontaneous mutants (Table 1). This report summarizes evidence of genetic control of intestinal and extraintestinal inflammation in these models, briefly outlines possible immunological mechanisms of enhanced genetic susceptibility and discusses the relevance of these observations to the pathogenesis of human IBD.

\section{SPONTANEOUS INFLAMMATORY MODELS}

The cotton-top tamarin and the recently developed $\mathrm{C}_{3} \mathrm{H} / \mathrm{HeJ}$ Bir substrain mouse develop chronic, spontaneously relapsing colitis. The mechanisms of intestinal inflammation in 
rats consanguins, des rats transgéniques et des mutants spontanés. Des rats Lewis consanguins, exposés à des polymères de la paroi cellulaire purifiée de bactéries, à l'indométhacine ou à des bactéries du grêle, ont développé une inflammation intestinale granulomateuse chronique avec fibrose et manifestations extraintestinales, alors que des rats Fisher (complexe majeur d'histocompatibilité semblable à ceux des rats Lewis) et des rats Buffalo stimulés de la même façon n'ont manifesté qu'une entérocolite à résolution spontanée, sans inflammation chronique, fibrose, granulomes ni inflammation extra-intestinale. Des modèles différentiels semblables d'inflammation intestinale apparaissent chez des souches de souris consanguines exposées à de l'acide trinitrobenzènesulfonique, à Citrobacter freundii ou soumises à un croisement en retour avec des souris présentant un déficit en récepteurs des cellules $T$. Le rôle dominant des antécédents génétiques dans l'induction de l'inflammation de l'intestin s'appuie encore sur la présence de colite spontanée qui se développe chez des souris mutantes, chez des tamarins, chez des rats et de souris rendues transgéniques par une microglobuline de l'antigène B27/2 des leucocytes humains avec élisions ciblées de certains gènes des lymphocytes $\mathrm{T}$ et des citokines immunorégulatrices. L'identification des mécanismes immunologiques de la susceptibilité génétique de l'hôte et de la base génétique de la colite spontanée devrait offrir de nouveaux renseignements sur la pathogenèse de la maladie inflammatoire de l'intestin chez l'humain.

\section{TABLE 1 \\ Genetic influence on animal models of intestinal inflammation \\ Spontaneous mutations (presumed) \\ Cotton-top tamarin \\ $\mathrm{C}_{3} \mathrm{H} / \mathrm{HeJ}$ Bir mouse \\ Genetically engineered models \\ Human leukocyte antigen-B27/ß2 microglobulin transgenic rats \\ Interleukin (IL)-2, IL-10, transforming growth factor-beta, alpha-beta- T cell receptor , $G_{i \alpha 2}$ knockout mice \\ Differential susceptibility of inbred rodent strains to induced inflammation \\ Peptidoglycan-polysaccharide enterocolitis \\ Indomethacin enterocolitis \\ Small bowel bacterial overgrowth- induced hepatobiliary inflammation \\ Trinitrobenzene sulphonic acid/ethanol colitis \\ Alpha-beta-T cell receptor-deleted colitis \\ Citrobacter freundii colitis}

these animals are unknown, but presumably are the result of a spontaneous genetic mutation because closely related strains do not develop colitis and aggressive searches have not identified environmental microbial pathogens.

At least 11 different species and hybrids of tamarins, a group of New World monkeys, spontaneously develop mild chronic colitis with mucosal atrophy (2). Cotton-top tamarins are unique in that they exhibit acute relapsing colitis complicated by adenocarcinoma of the colon (2-4). Captive cotton-top tamarins frequently develop a wasting syndrome characterized by weight loss, anorexia and diarrhea. An age-related chronic colitis is almost universally present by two years of age. Underlying chronic colitis is relatively mild, characterized by a thickened mucosa with hyperplastic, elongated crypts, pseudopolyps and mild mononuclear cell infiltration of the lamina propria. At any given time approximately one-half to two-thirds of marmosets have histological evidence of acute colonic inflammation, with neutrophilic infiltration, crypt abscesses and goblet cell depletion, but rarely have ulceration. Adenocarcinoma that complicates chronic colitis is not preceded by epithelial cell dysplasia or adenomatous polyps. Some tamarins develop chronic periportal inflammation with fibrosis.

The mechanism(s) of intestinal inflammation in cotton-top tamarins remains unclear. The inflammatory mediator profile of increased interleukin (IL)-1 and eicosanoids is characteristic of intestinal inflammation, and the colitis responds to sulfasalazine and a 5-lipoxygenase inhibitor (5). These marmosets share several biochemical and immunological alterations with ulcerative colitis patients. They have a selective reduction in mucus glycoprotein fraction IV which does not correlate with inflammatory activity (6). In addition their serum contains antineutrophil cytoplasmic autoantibodies which react with human, but not marmoset, neutrophils (7), and slightly increased concentrations of serum antibodies which stimulate cellmediated cytotoxicity to colonic epithelial cell-associated components (8). However, the precise genetic alteration that predisposes these marmosets to chronic, relapsing colitis with associated adenocarcinoma remains uncharacterized.

\section{$\mathrm{C}_{3} \mathrm{H} / \mathrm{HeJ}$ Bir SUBSTRAIN MOUSE COLITIS}

Birkenmeier and colleagues (9) have recently described a heritable form of murine colitis. It had become apparent that sporadic diarrhea and perianal ulceration were frequent in individual members of the Jackson Laboratory $\mathrm{C}_{3} \mathrm{H} / \mathrm{HeJ}$ mouse breeding colony but that no microbial pathogens were demonstrable. Selective breeding of mice that developed diarrhea resulted in a pedigree of mice in which there is a $50 \%$ incidence of spontaneous colitis. Colitis is more frequent in males $(67 \%$ incidence) than females (31\% incidence) and exhibits a seasonal variation (occurring more often in winter than summer). Inflammation follows a biphasic time course with onset around the time of weaning (three to five weeks of age), spontaneous resolution in most mice and a less predictable chronic phase. Clinical manifestations include occasional diarrhea, fecal blood (not grossly apparent) and perianal ulceration. Inflammation is most frequently found near the ileocecal valve but can involve the entire colon. Histological findings include focal linear ulcers and a mixed mononuclear and neutrophilic infiltration. Extraintestinal manifestations have not been described.

Attempts to identify the presumed spontaneous genetic mutation are in progress. Like the parent $\mathrm{C}_{3} \mathrm{H} / \mathrm{HeJ}$ strain, monocytes from mice with spon- 
taneous colitis are unresponsive to lipopolysaccharide (endotoxin) (10). Comparison of in vitro reactivity of $\mathrm{T}$ lymphocytes derived from parent strain and substrain mice with colonic cytokine profiles has not been reported. In preliminary studies, serum antibodies from $50 \%$ of $\mathrm{C}_{3} \mathrm{H} / \mathrm{HeJ}$ Bir mice react with luminal bacterial extracts compared with no detectable antibacterial antibodies from serum of $\mathrm{C}_{3} \mathrm{H} / \mathrm{HeJ}$ mice (11).

\section{GENETICALLY ENGINEERED MODELS}

Molecular engineering techniques permit selected genes to be overexpressed (transgenic) or deleted (embryonic stem cell recombination) in rodents. These methods have been powerful tools to determine the in vivo function of a targeted gene, and at times have provided unanticipated results. Deletion of several immunoregulatory cytokines, including IL-2, IL-10, transforming growth factor (TGF)-beta$-1, \mathrm{G}_{\mathrm{i} \alpha 2}$ and alpha or beta $\mathrm{T}$ cell receptor (TCR) chains, induces spontaneous colitis (12-15). These studies show that a single mutation of a key immunoregulatory cytokine, signalling molecule or T lymphocyte protein can lead to spontaneous intestinal inflammation, and that the colon is particularly susceptible to injury in immunodeficient hosts.

Overexpression of human leukocyte antigen (HLA)-B27/ß2 microglobulin $(\beta 2 \mu)$ in transgenic rats induces a systemic inflammatory syndrome in which the first manifestation is diarrhea, followed by arthritis, dermatitis, hair loss, psoriatic nail changes, epididymitis and a wasting syndrome $(16,17)$. Histological patterns of inflammation include focal chronic gastritis and duodenitis, and diffuse infiltration of the colonic lamina propria by mononuclear cells. Severely inflamed rats exhibit focal mucosal ulcerations and crypt abscesses in the colon. Cell transfer experiments demonstrate that HLA-B27/ $/ 32 \mu$ expressing bone marrow cells mediate the disease, and that $B 27 / \beta 2 \mu$ protein expression by nonimmune cells is neither necessary nor sufficient to cause disease (18). The absence of colitis, gastritis and ar-

TABLE 2

Differential susceptibility of inbred rats to experimental enterocolitis and systemic inflammation

\begin{tabular}{lll}
\hline High responder & Intermediate responders & Low responders \\
\hline Lewis & Sprague-Dawley & Fischer F344 \\
& Wistar & Buffalo \\
\hline
\end{tabular}

\begin{tabular}{lll} 
TABLE 3 \\
Differential host susceptibility of inbred mice to experimental colitis \\
\hline \begin{tabular}{lll} 
Model & High responders & Low responders \\
\hline $\begin{array}{l}\text { Trinitrobenzene sulphonic acid/ } \\
\text { ethanol }\end{array}$ & Balb/C, $\mathrm{C}_{3} \mathrm{H} / \mathrm{HeN}$ & $\mathrm{DBA} / 2, \mathrm{C} 57 / \mathrm{BL}$ \\
$\begin{array}{lll}\text { Citrobacter freundii } \\
\text { T cell receptor alpha knockout }\end{array}$ & $\mathrm{C}_{3} \mathrm{H} / \mathrm{HeJ}$ & $\mathrm{DBA} / 2 \mathrm{~J}$ \\
\hline
\end{tabular}
\end{tabular}

thritis in germ-free B27/ $\beta 2 \mu$ transgenic rats, attenuated inflammation in specific pathogen-free rats and inhibition by metronidazole clearly demonstrate the importance of luminal bacteria in initiation and perpetuation of intestinal inflammation and associated extraintestinal disease $(19,20)$. The incidence and onset of colitis and systemic inflammation depend on high copy numbers of HLA-B27/ $\beta 2 \mu$ (17). Compared with induced rat models of enterocolitis (see below), the incidence of intestinal inflammation in Lewis and Fischer rats expressing equivalent copy numbers of the HLA-B27/ $32 \mu$ transgene is similar, although extraintestinal inflammation is somewhat more frequent and rapid in onset in Lewis than Fischer rats (17).

\section{INDUCED INFLAMMATION IN INBRED RODENT STRAINS}

Differential susceptibility of inbred rodents to intestinal and systemic inflammation powerfully illustrates the key role of genetic regulation of chronic inflammation and its complications, including fibrosis.

Inbred rat strains: The author used three experimental models to demonstrate that, with identical stimuli, inbred Lewis rats develop chronic relapsing enterocolitis with extraintestinal inflammation and fibrosis whereas inbred Buffalo and Fischer F344 (major histocompatibility complex matched with Lewis) rats develop only transient intestinal inflammation and no systemic manifestations (Table 2). Lewis rats injected subserosally with the bacterial cell wall polymer peptidoglycanpolysaccharide (PG-PS) develop chronic, spontaneously relapsing, granulomatous enterocolitis with fibrosis and associated polyarthritis, granulomatous hepatitis, leukocytosis and anemia which persists for at least 16 weeks $(5,21)$. With identical exposure to PG-PS, Buffalo or Fischer rats exhibit only transient local inflammation, which resolves by 14 days, with residual damage and no chronic enterocolitis or extraintestinal manifestations. Outbred Sprague-Dawley rats develop chronic granulomatous enterocolitis, but the chronic intestinal inflammation is less pronounced and there is no extraintestinal disease (22).

In a second model, Lewis rats injected subcutaneously with indomethacin $(7.5 \mathrm{mg} / \mathrm{kg} / \mathrm{day}$ for two days) developed chronic mid-small bowel longitudinal ulcers with fibrosis and associated hepatobiliary inflammation, anemia and leukocytosis which persisted for at least 77 days, whereas Fischer rats had no residual inflammation 14 days after indomethacin (23). Similarly, Lewis rats - but not Buffalo or Fischer rats - developed chronic, fibrotic hepatobiliary inflammation in response to experimental small intestinal overgrowth of anaerobic bacteria following surgical creation of jejunal self-filling blind loops (24). In this model, Lewis rats develop clinical (hepatomegaly), biochemical (increased plasma aspartate aminotransferase), histological and cholangiographic evi- 


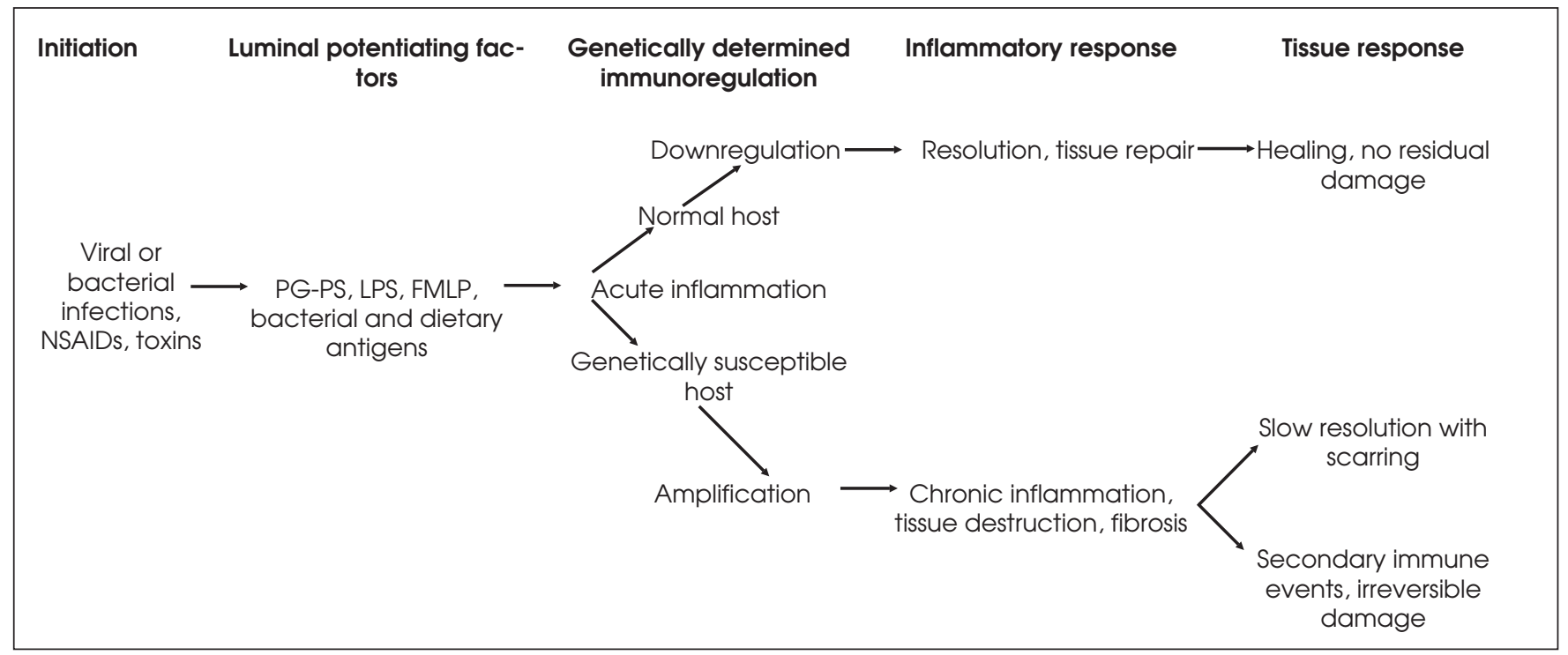

Figure 1) The influence of genetic susceptibility on chronicity of inflammation is presented. Episodic enteric infections, environment toxins and enhanced mucosal uptake of ubiquitous bacterial constituents induce transient injury in all hosts. The normal response is appropriate suppression of inflammation with no residual damage (upper arm). However, genetically susceptible hosts amplify the inflammatory response, which leads to chronic tissue damage. FMLP n-formyl-methionyl-leucyl phenylalanine; LPS Lipopolysaccharide, endotoxin; NSAIDs Nonsteroidal anti-inflammatory drugs; PG-PS Peptidoglycanpolysaccharide. Reprinted with permission from: Sartor RB. Microbial factors in the pathogenesis of Crohn's disease, ulcerative colitis and experimental intestinal inflammation. In: Kirsner JB, Shorter RG, eds. Inflammatory Bowel Disease, 4th edn. Baltimore: Williams Ë Wilkins, 1995:96-124

dence of hepatobiliary inflammation two to four weeks after formation of the self-filling blind loops. Wistar rats develop similar lesions by eight and 12 weeks, but Fischer and Buffalo rats fail to develop hepatobiliary injury despite very similar luminal bacterial concentrations in all rat strains. Thus, with identical stimuli, Lewis rats develop chronic, spontaneously relapsing inflammation with extraintestinal inflammation, but Buffalo and Fischer rats develop transient, self-limited inflammation with no local or systemic complications.

Lewis rats are high responders in a number of inflammatory models, including autoimmune encephalitis, thyroiditis, uveitis and arthritis (adjuvant, collagen and PG-PS-induced) $(25,26)$. Experimental data support two theories to explain mechanisms of enhanced susceptibility to inflammation in Lewis rats: defective acute hypothalamic/ pituitary/adrenal responses to IL-1 and PG-PS (27); and disordered regulation of the immune response. In support of the latter theory, Lewis rats have an increased ratio of cecal IL-1:IL-1 ra MRNA during the chronic phase of PG-PS-induced inflammation relative to resistant Buffalo and Fischer rats (21).
Moreover, noninflamed intestinal tissues from Lewis, but not Fischer and Buffalo, rats constitutively express MRNA for tumour necrosis factor and an IL-8-like molecule (28), suggesting that the mucosal immune system of the Lewis rat is in a 'primed' state. The author has also demonstrated that $\mathrm{T}$ lymphocytes regulate the chronic, relapsing granulomatous phase of PG-PS-induced enterocolitis and systemic inflammation based on observations that Lewis athymic (nude) rats fail to develop enterocolitis and arthritis, and that cyclosporin A prevents and treats chronic intestinal and systemic inflammation (29). These results complement the author's observations in IBD patients and observations by Bristol et al (30) that PG-PS stimulated peritoneal macrophages from Lewis rats have an increased IL-1:IL-1ra ratio relative to Buffalo rats. Patients with active Crohn's disease and ulcerative colitis have significantly increased tissue IL-1:IL-1 ra and MRNA protein ratios compared with controls $(31,32)$.

Inbred mouse strains: Beagley and coworkers (33) have reported that Balb/C and $\mathrm{C}_{3} \mathrm{H} / \mathrm{HeN}$ mice developed a chronic colitis upon repeated weekly administration of trinitrobenzene sul- phonic acid/ethanol enemas, but DBA/2 and C57/BL mice were resistant to chronic inflammation (Table 3 ). Similarly, $\mathrm{C}_{3} \mathrm{H} / \mathrm{HeJ}$ mice developed more extensive colonic inflammation and ulcerations than DBA/2J mice following experimental infection with Citrobacter freundii, although the two strains developed similar degrees of epithelial hyperplasia (34). However, inbred mouse strain susceptibility is not entirely consistent because Mombaerts et al (15) found that TCR-alpha chaindeficient mice on the $129 / \mathrm{SV}$ background and 129/SVxC $3 \mathrm{H} / \mathrm{He}$ crosses develop severe intestinal inflammation more rapidly (four to six months of age) and with a higher incidence than those 129/SV mice crossed with C57BL/6 or Balb/C strain, which develop a less severe disease with a slower onset. The only mouse strain that displayed consistent high susceptibility in these models was the $\mathrm{C} 3 \mathrm{H} / \mathrm{He}$ background $(\mathrm{C} 3 \mathrm{H} /$ $\mathrm{HeN}$ or $\mathrm{C} 3 \mathrm{H} / \mathrm{JHeJ}$ ), which is the parent strain for the $\mathrm{C} 3 \mathrm{H} / \mathrm{HeJ}$ Bir mice that spontaneously develop colitis (9).

\section{SUMMARY AND CONCLUSIONS}

The studies discussed above clearly demonstrate that the chronicity, ag- 
gressiveness and complications of induced intestinal inflammation depend on host genetic susceptibility. Furthermore, spontaneous mutation or altered expression of a single gene can induce spontaneous colitis. Genetically engineered models demonstrate that alteration of any of a number of key immunoregulatory cytokine or $\mathrm{T}$ lymphocyte gene products can lead to phenotypically similar intestinal inflammatory conditions. Furthermore, inbred rodent strains susceptible to induced intestinal inflammation exhibit immunoregulatory defects (Lewis rats increased IL-1:IL-1ra ratio and $\mathrm{C}_{3} \mathrm{H} / \mathrm{HeJ}$ lipopolysaccharide-unresponsiveness).

These observations in animal models suggest that human IBD can arise from a number of mutations of immunoregulatory molecules, supporting the concept of genetic heterogeneity for ulcerative colitis and Crohn's disease.

The author suggests that geneti-

\section{REFERENCES}

1. Yang H, Rotter JI. Subclinical markers of human IBD. In: Sutherland LR, et al, eds. Inflammatory Bowel Disease: Basic Research, Clinical Implications and Trends in Therapy. Boston, Dordrecht and London: Kluwer Academic Publishers, 1994:5-14.

2. Lushbaugh C, Humason G, Clapp N. Histology of colitis: Saguinus oedipus and other marmosets. Dig Dis Sci 1985;30:45S-51S.

3. Chalifoux IV, Brieland JK, King KW. Evolution and natural history of colonic disease in cotton-top tamarins (Saguinus oedipus). Dig Dis Sci 1985;30:54S-8S.

4. Madara JL, Podolsky DK, King NW, Sehgal PK, Moore R, Winter HS. Characterization of spontaneous colitis in cotton-top tamarins (Saguinus oedipus) and its response to sulfasalazine. Gastroenterology 1985;88:13-9.

5. Sartor RB. Animal models of intestinal inflammation: Relevance to IBD. In: MacDermott RP, Stenson W, eds. Inflammatory Bowel Disease. New York: Elsevier, 1991:337-54.

6. Podolsky DK, Madara JL, King N, et al. Colonic mucin composition in primates. Gastroenterology 1985;88:20-5.

7. Targan SR, Landers CJ, King NW, Podolsky DJ, Shanahan F. Ulcerative colitis-linked antineutrophil cytoplasmic antibody in the cottontop tamarin model of colitis. Gastroenterology 1992;102:1493-8. cally determined defects in immunoregulation or perhaps mucosal barrier integrity can alter the delicate balance among phlogistic luminal bacterial constituents, dietary antigens and mucosal protective forces, and proposes that the genetic susceptibility of high responding hosts (Lewis rats and perhaps IBD patients) is due to an inability to downregulate appropriately the inflammatory response to ubiquitous luminal antigens, probably of bacterial origin (35). This theory predicts that events initiating inflammation may be nonspecific (selflimited infection, nonsteroidal antiinflammatory drugs, toxins) and produce acute inflammation of similar degree in all hosts (Figure 1). The normal, genetically resistant host appropriately downregulates inflammation, which heals with no residual damage. However, the genetically susceptible host (Lewis rat, IBD patient), due to de-

8. Winter HS, Crum PM Jr, King NW, Sehgal PK, Roche JK. Expression of immune sensitization to epithelial cell-associated components in the cotton-top tamarin: A model of chronic ulcerative colitis. Gastroenterology 1989;97:1075-82.

9. Sundberg JP, Elson CO, Bedigian H, et al. Spontaneous, heritable colitis in a new substrain of $\mathrm{C} 3 \mathrm{H} / \mathrm{HeJ}$ mice. Gastroenterology 1994;107:1726-35.

10. McCabe RP, Mills T, Ridwan B, et al. Immunologic reactivity in $\mathrm{C} 3 \mathrm{H} / \mathrm{HeJ}$ mice with spontaneous colitis. Gastroenterology 1993;104:A739.

11. Brandwein SL, McCabe RP, Dadrat $\mathrm{A}$, et al. Immunologic reactivity of colitic $\mathrm{C} 3 \mathrm{H} / \mathrm{HeJ}$ Bir mice to enteric bacteria. Gastroenterology 1994;106:A656.

12. Sadlack B, Merg H, Schorle H, et al. Ulcerative colitis-like disease in mice with a disrupted interleukin-2 gene. Cell 1993;75:253-61.

13. Kuhn R, Lohler J, Rennick D, Rajowsky K, Muller W.

Interleukin-10-deficient mice develop chronic enterocolitis. Cell 1993;75:263-79.

14. Kulkarni AB, Huh CG, Becker D, et al. Transforming growth factor $\beta$ null mutation in mice causes excessive inflammatory response and early death. Proc Natl Acad Sci USA 1993;90:770-4.

15. Mombaerts P, Mizoguchi E, Grusby M, et al. Spontaneous development of inflammatory bowel disease in $\mathrm{T}$ cell fective immunosuppression, amplifies the inflammatory response to develop aggressive tissue injury, fibrosis and extraintestinal inflammation. Better understanding of genetically determined defects in immunoregulation of the Lewis rat, and $\mathrm{C}_{3} \mathrm{H} / \mathrm{HeJ}$ and $\mathrm{C}_{3} \mathrm{H} / \mathrm{HeN}$ mice, and identification of the spontaneous genetic mutation(s) of the $\mathrm{C}_{3} \mathrm{H} / \mathrm{HeJ}$ Bir mouse should lead to valuable insights into the genetic regulation of experimental chronic intestinal and extraintestinal inflammation that can be rapidly tested in IBD patients.

ACKNOWLEDGEMENTS: This work was supported by USPHS grants DK 40249, DK 47700 and DK 34987, and the Crohn's and Colitis Foundation of America. The authors gratefully acknowledge the expert secretarial assistance of Robert Tuttle and Shirley Willard.

receptor mutant mice. Cell 1993; 75:275-82.

16. Hammer RE, Maika SD, Richardson JA, Tang J, Taurog JD. Spontaneous inflammatory disease in transgenic rats expressing HLA-B27 and human $\beta_{2} \mathrm{~m}$ : An animal model of HLA-B27associated human disorders. Cell 1990;63:1099-112.

17. Taurog JD, Maika SD, Simmons WA, Breban M, Hammer RE. Susceptibility to inflammatory disease in HLA-B27 transgenic rat lines correlates with the level of B27 expression. J Immunol 1993;150:4186.

18. Breban M, Hammer RE, Richardson JA, Taurog JD. Transfer of the inflammatory disease of HLA-B27 transgenic rats by bone marrow engraftment. J Exp Med 1993;178:1607-16.

19. Taurog JD, Richardson JA, Croft JT, et al. The germfree state prevents development of gut and joint inflammatory disease in HLA-B27 transgenic rats. J Exp Med 1994;180:2359-64.

20. Rath HC, Bender DE, Grenther T, et al. Normal bacteria stimulate colonic, gastric and systemic inflammation in HLA-B27/ß2 m transgenic rats. Gastroenterology. (In press)

21. McCall RD, Haskill S, Zimmerman E, et al. Tissue IL-1 and IL-1 receptor antagonist expression in enterocolitis in resistant and susceptible rats. Gastroenterology 1994;106:960-72.

22. Sartor RB, Cromartie WH, Powell DW, et al. Granulomatous enterocolitis induced in rats by purified bacterial cell wall fragments. Gastroenterology 1985;89:587-95.

23. Sartor RB, Bender DE, Holt LC. Susceptibility of inbred rat strains to intestinal and extraintestinal inflammation induced by indomethacin. Gastroenterology 1992;102:A690. 
24. Lichtman SN, Sartor RB, Schwab JH, Keku J. Hepatic inflammation in rats with experimental small bowel bacterial overgrowth. Gastroenterology 1990;98:414-23.

25. Moore MJ, Singer DE, William RM. Linkage of severity of experimental allergic encephalomyelitis to the rat major histocompatibility locus. J Immunol 1980;124:1815-20.

26. Schwab JH. Phlogistic properties of peptidoglycan-polysaccharide polymers from cell walls of pathogenic and normal-flora bacteria which colonize humans. Infect Immun 1993;61:4535-9.

27. Sternberg EM, Hill JM, Chrousos GP, et al. Inflammatory mediator-induced hypothalamic-pituitary-adrenal activation is defective in streptococcal cell wall arthritis-susceptible Lewis rats. Proc Natl Acad Sci USA 1989;86:2374-8.

28. McCall RD, Haskill JS, Sartor RB. Constitutive expression of TNF $\alpha$ and of an IL-8 like gene is associated with genetic susceptibility to chronic granulomatous enterocolitis in inbred rats. Gastroenterology 1993;104:A740.

29. Sartor RB, Bender DE, Allen JB, et al. Chronic experimental enterocolitis and extraintestinal inflammation

are T lymphocyte dependent. Gastroenterology 1993;104:775A.

30. Bristol LA, Durum SK, Eisenberg SP. Differential regulation of group A streptococcal peptidoglycan polysaccharide (PG-APS)-stimulated macrophage production of IL- 1 by rat strains susceptible and resistant to PG-APS-induced arthritis. Cell Immunol 1993;149:130-43.
31. Isaacs KL, Sartor RB, Haskill JS. Cytokine mRNA profiles in inflammatory bowel disease mucosa detected by PCR amplification. Gastroenterology 1992;103:1587-95.

32. Isaacs KL, Sartor RB, Haskill JS. Relative expression of IL-1 and IL-1 receptor antagonist in IBD. Gastroenterology 1992;102:A729.

33. Beagley KW, Black DA, Elson CO. Strain differences in susceptibility to TNBS-induced colitis. Gastroenterology 1991;100:A560.

34. Barthold, SW, Osbaldiston GW, Jonas AM. Dietary, bacterial, and host genetic interactions in the pathogenesis of transmissible murine colonic hyperplasia. Lab Anim Sci 1977;27:938-45.

35. Sartor RB. Current concepts of the etiology and pathogenesis of ulcerative colitis and Crohn's disease. Gastroenterol Clin North Am. (In press) 


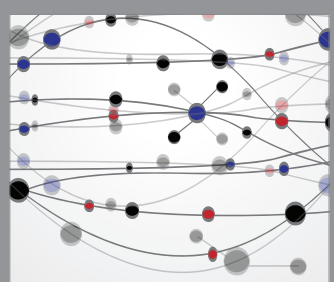

The Scientific World Journal
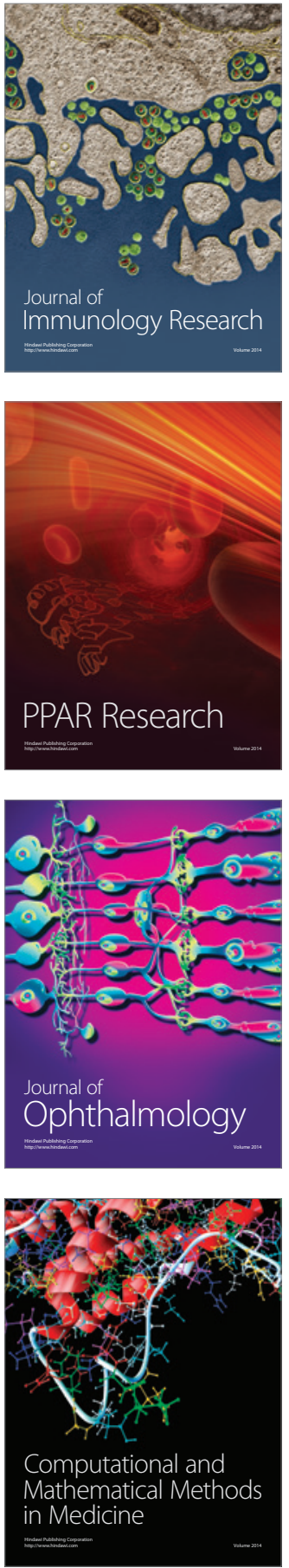

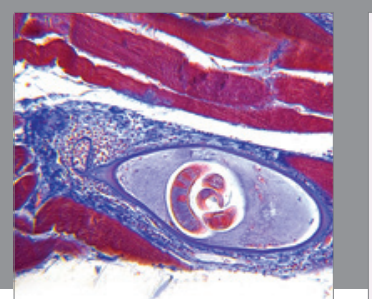

Gastroenterology Research and Practice

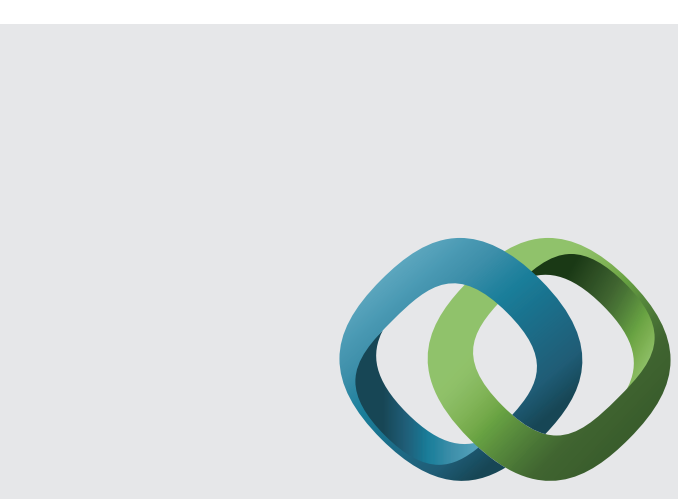

\section{Hindawi}

Submit your manuscripts at

http://www.hindawi.com
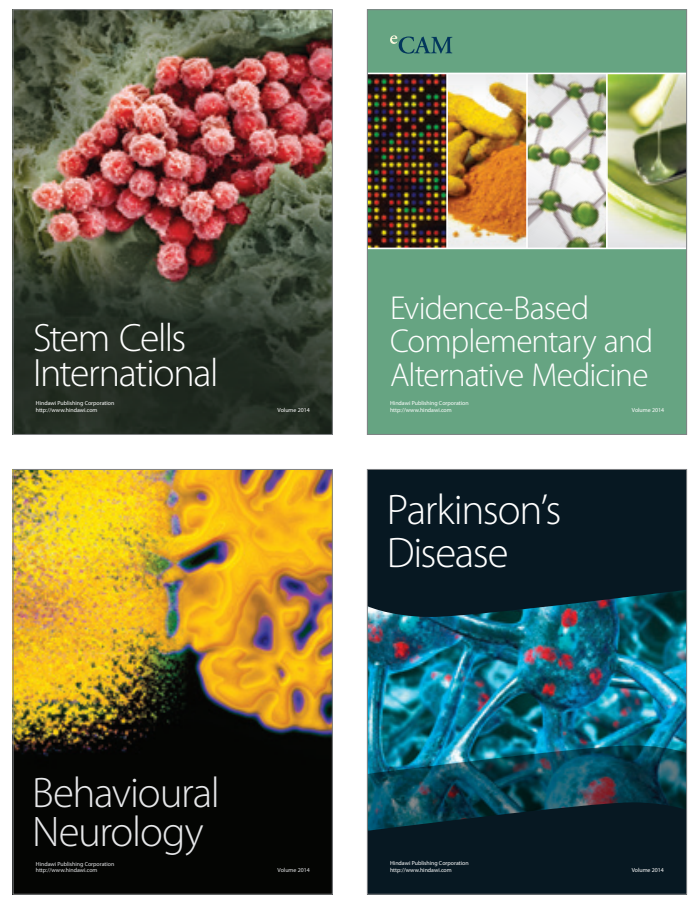
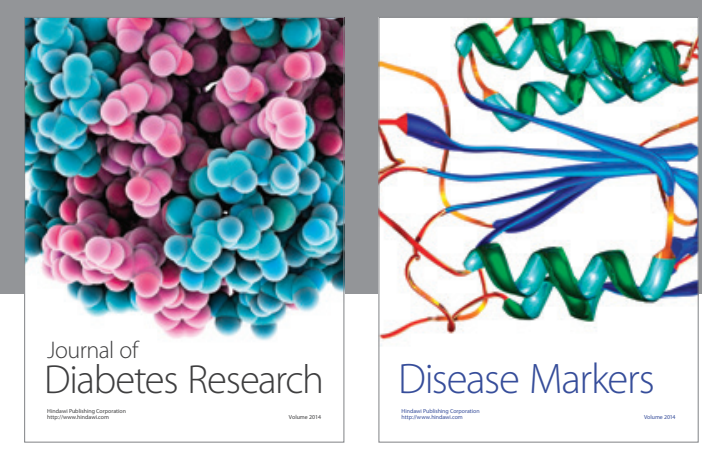

Disease Markers
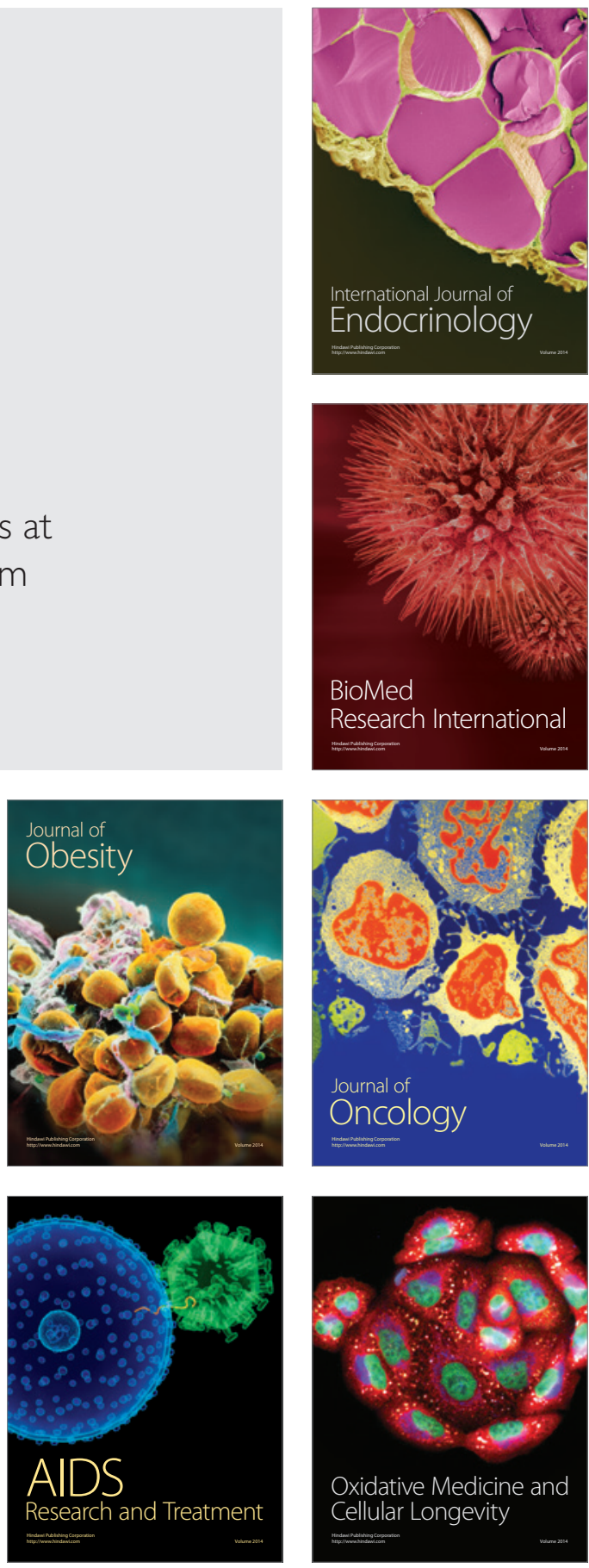